\title{
Blaž Zabel
}

\section{Intertekstualnost v starogrški tragediji - primer Evripidovega Oresta}

$\mathrm{V}$ članku bom razpravljal o vlogi intertekstualnost pri razumevanju klasične tragedije, predvsem Evripidovega Oresta. Najprej bom na kratko orisal glavne poteze teorij intertekstualnosti in njihovo vlogo teh v klasični filologiji. V drugem delu članka bom razpravljal predvsem o Evripidovem Orestu in njegovih intertekstualnih značilnostih. Zatem bom predstavil nekaj primerov aluzij oziroma intertekstualnih navezav te tragedije na Orestejo, Medejo, Ifigenijo pri Tavrijcih in Odisejo, nato pa bom razpravljal o zaključkih Frome Zeitlin, ki intertekstualnost Oresta povezuje z izčrpanjem tragedije kot žanra, premikom iz mita $\mathrm{v}$ fikcijo in novim pojmovanjem literature kot avtonomnega ter samo-refleksijskega umetniškega dela. V zaključku bom predstavil tri možne ugovore proti tej poziciji. Najprej bom zagovarjal stališče, da je prav ritualni in družbeni kontekst tragedije, ki so ga obiskovalci oprizoritve Oresta nedvomno poznali in razumeli, v nasprotju s konceptom intertekstualnosti. Nato se bom posvetil vlogi jezika $\mathrm{v}$ pesništvu in tragediji ter poskušal pokazati, da je bila narava tragiškega jezika drugačna od strukturalističnega pojmovanja jezika kot sistema znakov. Na koncu bom podal še razmislek o ontologiji literarnega dela in ontologiji ustne tradicije ter poskušal pokazati, da sta prav ne-literarni kontekst in ne-literarna tradicija $\mathrm{v}$ nasprotju $\mathrm{z}$ idejo intertekstualnosti, ki se bistveno opira na razumevanje literature kot zapisanega teksta.

\section{KRATEK PREGLED KONCEPTA INTERTEKSTUALNO- STI V LITERARNI VEDI}

O tem, kaj naj bi pojem »intertekstualnost « označeval, se razhajajo celo sami raziskovalci odnosov med besedili, ${ }^{1}$ zato morda ne bo odveč, če posku-

1 Cf. Martin, »Intertextuality: An Introduction«; Allen, Intertextuality. 
šam v nekaj stavkih predstaviti razvoj koncepta. ${ }^{2}$ Čeprav se je ideja intertekstualnosti rodila ter odraščala $v$ kontekstu francoskega strukturalizma in čeprav je strukturalistično pojmovanje intertekstualnosti še danes izjemno vplivno, je potrebno opozoriti, da so nekateri misleci razvili koncepte intertekstualnosti, ki ne sprejemajo strukturalističnih načel. ${ }^{3}$ A kot se bo pokazalo v nadaljevanju, je imelo prav strukturalistično razumevanje pomemben vpliv na klasično filologijo in je vplivalo tudi na interpretacije Evripidovega Oresta.

Kot prvo predstavnico teorij intertekstualnosti lahko najverjetneje označimo kar Julio Kristevo, ki je termin tudi skovala ${ }^{4}$ in se v svoji teoriji opirala na strukturalizem in Mihaila Bahtina. ${ }^{5}$ Začetnik strukturalizma Ferdinand de Saussure je intertekstualnost zaznamoval predvsem s svojim razumevanjem jezikovnega znaka ter pojmovanjem jezika kot avtonomnega sistema. ${ }^{6}$ Jezikovni znak Saussure deli na označevalca, ki predstavlja zvočno ali vizualno podobo znaka, in označenca, ki pa ne predstavlja objekta v stvarnem svetu, temveč določen koncept tega predmeta. Naslednjo pomembno točko Saussurove pogleda na jezik kot sistem predstavlja arbitrarnost odnosa med označencem in označevalcem. Označevalec namreč pojmuje označenca zgolj v ambivalentnem odnosu do vseh ostalih označevalcev, kar pomeni, da je označevalec z označencem povezan zgolj zaradi razlike od vseh ostalih označevalcev. Strukturalizem torej jezik razume kot sistem, ki se nanaša zgolj sam nase. Jezikovni znak ne pojmuje resničnega objekta $\mathrm{v}$ svetu, vendar zgolj nek koncept, povezava med označencem in označevalcem je arbitrarna in nastane zgolj zaradi razlike med posameznim znakom in vsemi ostalimi znaki. Jezik je torej avtonomen in zaprt sistem.

Mihail Bahtin je svojo teorijo jezika razvil predvsem kot odgovor na $\mathrm{v}$

2 Slovenski publiki je verjetno znana izdaja 45. zvezka zbirke Literarni leksikon z naslovom Interkstualnost Marka Juvana. Poleg tega odličnega pregleda zgodovine pojma intertekstualnosti $\mathrm{v}$ literarni teoriji po svetu in pri nas sta omembne vredna še dva pregleda - Graham Allen Intertextuality in Mary Orr Intertextuality: Debates and Contexts.

3 Med slednjimi velja na primer omeniti vsaj Harolda Blooma, ki se v svojem razmisleku opre na romantično in hermenevtično tradicijo, zaradi česar Juvan med drugim ugotavlja: »Toda od poststrukturalistov se Bloom močno razlikuje, zato je bolj teoretik vpliva in tradicije kot intertekstualnosti« (Juvan, Intertekstualnost, 79). Po Bloomovem prepričanju je vsak pesnik del določene tradicije, ki jo nujno tudi posnema. Vendar pa poskuša biti vsak pesnik in vsako pesniško delo ob enem tudi edinstveno in inovativno. Ker se pesnik želi uveljaviti kot samostojna identiteta, ga nujno zaznamuje tudi »strah pred vplivom«. Bloom se opre na psihoanalitično tradicijo, ko trdi, da je vsaka pesniška dejavnost pravzaprav uporaba figurativnega jezika in obrambnih mehanizmov prisvajanja ter prikrajanja drugih literarnih del. Literarno delo torej vedno odlikuje določena dvojnost; posnemanje velikih del tradicije ter inovativnost, ki nastane iz upora zoper to isto tradicijo.

4 Cf. Martin, "Intertextuality«; Schmitz, Modern Literary Theory and Ancient Texts: An Introduction; Juvan, Intertekstualnost.

5 Cf. Allen, Intertextuality; Juvan, Intertekstualnost.

6 Za zares odličen in izjemno razumljiv prikaz Saussurovega pojmovanja jezika bralcu predlagam delo Toma Virka Moderne metode literarne vede in njihove filozofsko teoretske osnove. 
tistem času prevladujoči ruski formalizem ${ }^{7}$ in saussurovski strukturalizem. ${ }^{8}$ Bahtin je s sodelavci razvil filozofijo jezika, ki je Juli Kristevi pripravila podlago za razvitje koncepta intertekstualnosti. Za razliko od strukturalistov Bahtin jezik razume predvsem kot živ jezik ${ }^{9}$ (torej kot jezik v rabi) in zahteva, glede na Saussurov razloček med jezikom in govorom, ${ }^{10}$ preučevanje slednjega. Ker je vir govora posameznik ali skupina govorcev, govor vedno izhaja iz določenega družbenega konteksta. Prav zaradi družbene pogojenosti govora je Bahtin jezik razumel kot dialog, torej kot govorno komunikacijo, ki pa je kot taka odvisna od drugih govorov. Ker je govor vedno jezik v rabi in gre torej za izjavo, ki jo izreka družbeni subjekt nekemu naslovniku, je govor določen $\mathrm{z}$ družbenim kontekstom poročevalca in sprejemnika. $\mathrm{V}$ tem smislu je torej izjava odvisna od drugih govorov, ki tvorijo družbeni kontekst njene dialoškosti. V tej odvisnosti govora od drugih govorov je že mogoče videti osnovo za kasnejše pojmovanje intertekstualnosti pri Kristevi.

Kot smo že dejali, se je Julia Kristeva v zasnutju koncepta intertekstualnosti oprla na francoski strukturalizem in Bahtinovo filozofijo jezika, oboje pa uskladila s teoretsko smerjo, ki jo danes označujemo kot poststrukturalizem in jo je v poznih šestdesetih letih utemeljila skupina raziskovalcev, zbrana okrog revije Tel Quel. Sprva se je Kristeva oprla na Bahtinov koncept dialogizma, vendar pa je Bahtinovo osredotočenost na subjekt komunikacije nadomestila $\mathrm{z}$ bolj abstraktnim pojmom strukture teksta. ${ }^{11}$ Besedilo torej beremo in razumevamo na dveh ravneh: horizontalno od avtorja proti sprejemniku ${ }^{12}$ in vertikalno od teksta proti kontekstu, pri čemer slednjo raven Kristeva razume kot pomen, ki se oblikuje v razmerju med tekstom in predhodnimi besedili. S svojo teorijo intertekstualnosti se je Kristeva oprla tudi na sočasno izdajo Saussurovih anagramov. ${ }^{13}$ Znamenito razkritje Saussurovega »nočnega « iskanja anagramov je Kristevi služilo kot dokaz za intertekstualnost jezikovnega znaka. Anagrami namreč besedilo (oziroma pesniški jezik) podvajajo na tak

7 Ruski formalizem se je razvil iz težnje po znanstvenem preučevanju literarnega besedila, raziskovalci pa so poskušali poiskati bistvo literature oz. literarnost samih besedil. Za ruski formalizem je torej značilno imanentistično preučevanja literature (torej tako, ki ob strani pušča različne zunajliterarne elemente), hkrati pa so se ruski formalisti osredotočili predvsem na formo literarnih besedil in so zavračali vse oblike tematskih analiz.

8 Allen, Intertextuality, 16; Juvan, Intertekstualnost, 110.

9 Vološinov, Marxism and the Philosophy of Language.

10 Saussure med seboj razlikuje govor (parole) in jezik (langue). Z jezikom francoski jezikoslovec pojmuje sistem vseh jezikovnih elementov, ki ga urejujejo določena pravila, govor pa mu predstavlja vsakršno živo manifestacijo jezika. Saussure se je zavzemal predvsem za jezikoslovje, ki bi preučevalo jezik kot sistem znakov in ne govorice. Zgolj tako razumljeno jezikoslovje je po njegovem mnenju znanstveno.

11 Allen, Intertextuality, 36.

12 To raven besedila Kristeva sicer v svoji študiji o Bahtinu z naslovom Bakhtine, le mot, le dialogue et le roman še omenja, vendar jo proti koncu študije povsem opusti (cf. Juvan, Intertekstualnost, 122), kasneje pa opusti tudi idejo subjekta besedila (Allen, Intertextuality, 40-42). Če Bahtin s konceptom dialoga in govorne interakcije še pojmuje "razmerja med subjekti kot osebami«, pa Kristeva pod vplivom poststrukturalistične »destrukcije znaka, teksta in subjekta« tekst povsem desubjektivizira (Juvan, Intertekstualnost, 125).

13 Starobinski, Les mots sous les mots. Les anagrammes de Ferdinand de Saussure. 
način, da med elementi besedila nastane neskončno število pomenskih kombinacij. Jezikovni znak zato že "po definiciji predpostavlja neskončno kombinacij in možnih povezav ${ }^{14}$ med označencem in označevalcem. ${ }^{15}$

V sedemdesetih letih je Kristeva začela opozarjati na (zlo)rabo pojma »intertekstualnost«, ki so ga različni raziskovalci uporabljali pri iskanju virov za različna literarna besedila, njihovih vsebinskih povezav ter paralelnih analiz, ${ }^{16}$ zato je pojem opustila in ga nadomestila $\mathrm{z}$ izrazom »transpozicija", ki jo je opredelila kot "prehod iz enega sistema znakov v drugega «. ${ }^{17} \mathrm{~S}$ transpozicijo torej Kristeva označuje spreminjanje teksta glede na historični in družbeni kontekst. To pravzaprav pomeni, da vsak znakovni sistem vedno vsebuje množico drugih, preoblikovanih jezikovnih sistemov, oziroma da vsako besedilo vključuje druga besedila in s tem druge kontekste, ki jih preoblikuje v nov sistem znakov.

Najbolj nazorno je pojem intertekstualnosti definiral Roland Barthes. ${ }^{18}$ Barthes razume tekst kot drsečo verigo označevalcev, prav zaradi odsotnosti trdnega pomena oziroma označenca pa je tekst le fragment jezika, umeščen $\mathrm{v}$ perspektive drugih jezikov. ${ }^{19}$ Barthesova odmevna teza o $» s m r t i$ avtorja $\aleph^{20}$ je v samem jedru njegovega razumevanja intertekstualnosti. ${ }^{21}$ Barthes avtorja povezuje predvsem s pomensko enoznačnim delom. V nasprotju z delom pa tekst zaznamuje odprta struktura besedila, zato je bralec tisti, ki ob branju postane tvorec pomena. Tega sicer ne smemo razumeti, kot da pomen besedila določa sam bralec oziroma da je bralec tisti, ki označevalcem pripiše točno določen označenec. Ne, tudi bralec je pravzaprav to, kar je že prebral (Barthes v tej zvezi uporablja izraz dejà $l u$, »že prebrano«), tudi bralec je »intertekstualen«.V šestdesetih letih 20. stoletja in pozneje je v teorijah intertekstualnosti začela prevladovati poststrukturalistična usmeritev. Kljub vsemu pa je nekaj avtorjev še vztrajalo pri osnovnih strukturalističnih izhodiščih. Med njimi tudi dva, ki sta pomembno zaznamovala idejo intertekstualnosti: Michael Riffaterre in

14 Kristeva, Desire in Language, 69.

15 Poleg Saussura je bila za misel Kristeve produktivna tudi v tistem času izjemno popularna psihoanaliza $z$ Lacanom na čelu. Tako je francoska raziskovalka razvila celo svoje pojmovanje faz otrokovega razvoja in vstopa $v$ jezik, na osnovi te teorije pa je ločevala fenotekst in genotekst. Če fenotekst predstavlja tekst s trdno jezikovno strukturo in enotnim subjektom izjavljanja, pa genotekst izhaja iz nagonskih vzgibov nezavednega. Poezija in pesniški jezik torej artikulirata človekove gonske vzgibe v družbeno sprejemljivo obliko, s tem pa se hkrati razkrije primarna razbitost identitete subjekta, ki se poenoti šele v družbenih in jezikovnih zakonih.

16 Kristeva, La révolution du langage poétique, 59-60; cf. Juvan, Intertekstualnost, 129; McAfee, Julia Kristeva, 26.

17 Kristeva, La révolution du langage poétique, 59.

18 Allen, Intertextuality, 61.

19 Skladno s tem, je tudi naloga tekstne analize, da pokaže odsotnost označenca v besedilu, kar je Barthes večkrat demonstriral s poskusi konkretne analize besedil. Tako je na primer v delu $S / Z$ delo Sarrasine razdelil na posamezne elemente (imenoval jih je leksije) ter vsaki leksiji pripisal svoj določen kod. S tem je poskušal pokazati na odprtost in dinamičnost teksta, $v$ katerega se vpisujejo različni glasovi in kodi. Za kratko predstavitev Barthesove analize v delu $S / Z$ glej Koron, Sodobne teorije pripovedi, 103-105.

20 Barthes, „Smrt avtorja«.

21 Allen, Intertextuality, 70. 
Gérard Genette. ${ }^{22}$ Michael Riffaterre je tako prepričan, da literarna besedila niso referencialna, kar pomeni, da se ne nanašajo na objekte izven besedila, ampak svoj pomen dobijo iz semiotične strukture oziroma iz inter-teksta. ${ }^{23}$ Branje besedila tako poteka na dveh ravneh: prvi nivo branja poskuša jezikovne znake povezati z realnimi izven-besedilnimi referenti, ob tem načinu branja pa bralec trči na agramatičnosti, torej besede (ali širše besedne sklope), ki v samem besedilu nimajo smiselnega pomena na referencialni ravni. Če agramatičnosti v literarnem besedilu beremo referencialno oziroma »dobesedno «, potem delujejo nesmiselno (pomislimo samo na metafore!). Da bi bralec agramatičnosti osmislil, mora preiti na drugo raven branja in razumeti tudi semiotično strukturo, ki tvori ne-referencialni kontekst besedila. Tako bralec v besedilu, da bi agramatičnosti in s tem tudi literarno besedilo osmislil, poišče matrico, ki je »hipotetična in torej zgolj gramatična ter leksična aktualizacija strukture «. ${ }^{24}$ Matrica je torej hipotetična struktura besedila v »sociolektu«, torej v enoznačnem in razumljivem diskurzu. Literarno besedilo je pravzaprav aktualizacija te strukture, oziroma rečeno enostavneje, ubeseditev matrice. S takšnim pojmovanjem razumevanja in interpretacije literarnega dela je povezan tudi Riffaterrov koncept intertekstualnosti. Kot že avtorji pred njim tudi Riffaterre poudarja, da intertekstualnost ne pomeni vpliva določenega besedila na drugo besedilo, vendar pa moramo ob branju, če seveda želimo določeno literarno besedilo tudi razumeti, vedno predpostavljati obstoj inter-teksta, ki ga literarno besedilo transformira na tak ali drugačen način. Takšno ne-transformirano obliko literarnega besedila Riffaterre imenuje tudi hipogram. Po Riffaterrovem mnenju je lahko intertekstualno zgolj literarno besedilo, saj zgolj literatura odstopa od sociolektov in artikulira svoj lasten »idiolekt«, prav to pa je tudi pogoj umetniškosti besedila. Kot smo videli že zgoraj, idiolekt res da temelji na sociolektu, torej enoznačno referencialnem jeziku, vendar pa sam na sebi ni enoznačen, pogoj te kompleksnosti (oz. pogoj agramatičnosti) pa je prav intertekstualnost oziroma navezovanje na druga literarna besedila in hkrati tudi druge sociolekte. Pomen literarnega besedila je torej odvisen od intertekstualnega navezovanja na druga besedila.

Podobno kot Michael Riffaterre je tudi Gérard Genette v svojem pojmovanju intertekstualnosti sledil osnovnim strukturalističnim izhodiščem. Za razliko od zgoraj predstavljenih mislecev Genette meni, da je intertekstutalnost značilnost zgolj nekaterih literarnih besedil. Pravzaprav je Genette fenomen intertekstualnosti v delu z naslovom Palimpsesti imenoval transtekstualnost, razdelil pa jo je na pet različnih tipov: intertekstualnost, paratekstualnost, metatekstualnost, hipertekstualnost in arhitekstualnost. V vsakem literarnem delu so seveda prisotne vse oblike transtekstualnosti, ki »so v recipročnem sti-

22 Allen, Intertextuality, 115.

23 Riffaterre, Semiotics of Poetry.

24 Riffaterre, Semiotics of Poetry, 19. 
$\mathrm{ku}$ in se prepletajo ${ }^{25} \mathrm{~S}$ pojmom intertekstualnost Genette pojmuje razmerje med dvema besediloma ali med več besedili, ki se pojavlja bodisi kot citat, plagiat ali aluzija. Paratekst je vrsta besedila, ki spremlja literarno delo in $\mathrm{s}$ tem usmerja bralčevo recepcijo - primeri takšnega besedila so opombe, predgovor, širše pa intervjuji z avtorjem, avtorjeve izjave, pisma in knjiga v svoji materialni eksistenci. Tretji tip transtekstualnosti je metatekstualnost, ki poenostavljeno pomeni komentar k drugemu besedilu. Takšna oblika metateksta bi bila na primer literarna kritika. Tudi arhitekstualnost usmerja bralčeva pričakovanja in recepcijo literarnega dela, vendar pa ne direktno kot paratekst, temveč z naslonitvijo literarnega dela na določeno žanrsko tradicijo, literarno zvrst ali kakšno drugo konvencijo. Največ pozornosti Genette posveti hipertekstualnosti, saj z njo pojmuje vsako besedilo, ki se opira na neko drugo besedilo in hkrati ni metatekst. Po Genettovem mnenju je bistveno, da se hipertekst zavestno opre na določen hipotekst oziroma na določeno predlogo. Sam kot primer navede dve deli, Eneido in pa Uliksesa Jamesa Joycea, ki se obe opirata na Homerjevo Odisejo (o tem primeru več pozneje). ${ }^{26}$ Kot smo videli v tem kratkem prikazu začetkov intertekstualnosti in njenega razvoja $\mathrm{v}$ kontekstu strukturalizma in poststrukturalizma, je glavno vodilo mislecev koncepcija jezika kot sistema znakov, prav ta struktura pa je glavni predmet strukturalističnih preučevanj. Bolj kot posamezno literarno delo tako raziskovalce zanima literarni sistem in medsebojna razmerja med posameznimi literarnimi deli. Prav to je tudi skupna nit vseh teorij intertekstualnosti: posamezno literarno delo pripada zaprtemu sistemu, v katerega so vključena vsa ostala literarna dela, in vsako literarno delo dobi svoj pomen v razmerju do drugih literarnih del..$^{27}$ Jonathan Culler tako ugotavlja, da je predmet preučevanja strukturalistov predvsem teorija literature (lahko bi rekli tudi preučevanje literature kot sistema) in ne interpretacija literarnih del, pri tem pa strukturalizem literarni diskurz razume kot sistem, ki je ločen od diskurzov »vsakdanjega življenja«. ${ }^{28}$ Strukturalisti literaturo torej razumejo kot zaprt, samozadosten in avtonomen sistem, ki svoj pomen pridobiva zgolj sam iz sebe. Če na primer pomislimo na tragedijo: določeno besedilo bo bralec interpretiral kot tragedijo prav zaradi odnosa tega literarnega besedila do vseh drugih literarnih del, ki so, ali niso tragedije (na primer, $\mathrm{v}$ obliki potrditev podobnost $\mathrm{z}$ drugimi tragedijami in ne-podobnosti $\mathrm{z} »$ ne-tragičnimi« literarnimi deli) ${ }^{29}$.

25 Genette, Palimpsests, 7.

26 Seveda je mogoče, da je hipotekst izgubljen: v tem primeru hipertekstualne relacije pač ni mogoče potrditi. Genette celo trdi, da so vsa literarna dela potencialno hipertekstualna, a je obenem mogoče vsako delo brati tudi kot samostojno besedilo brez predloge. Prav ta točka Genettove teorije pa je bila najpogosteje kritizirana, saj implicira, da je nazadnje prav bralec tisti, ki se odloča, ali bo določeno besedilo razumel kot intertekstualno ali ne. Nenazadnje pa pomeni tudi to, da sta $\mathrm{v}$ literarnem delu intertekstualnost in tekstualnost ločena.

27 Paralele s Saussurjevim pojmovanjem jezika, kjer je povezava označevalca $\mathrm{z}$ označencem odvisna od razmerja med vsemi označevalci, so seveda očitne.

28 Cf. Culler, Structuralist Poetics, 131-152.

29 Cf. Allen, Intertextuality, 97-98. 


\section{INTERTEKSTUALNOST V KLASIČNI FILOLOGIJI?}

Z zgornjim pregledom sem poskušal pokazati, kako se je $\mathrm{v}$ literarni teoriji razvijala in izoblikovala ideja intertekstualnosti. Iz teh teoretičnih osnov se je pojmovanje intertekstualnosti hitro razširilo tudi v druge humanistične discipline, na primer na področje ženskih študij ali postkolonialnih študij, ${ }^{30} \mathrm{pa}$ tudi v teorijo arhitekture in umetnostno zgodovino, ${ }^{31}$ filma, ${ }^{32} \mathrm{v}$ muzikologijo ${ }^{33}$ itd. Klasična filologija pri tem seveda ni nobena izjema. Že kratek pregled dela Modern Literary Theory and Ancient Texts Thomasa A. Schmitza pokaže, da koncept intertekstualnosti predstavlja eno izmed osrednjih teoretskih usmeritev preučevanja klasičnih besedil. Kljub vsemu si velja nekoliko natančneje pogledati, kako je intertekstualnost vstopila $\mathrm{v}$ metodološki repertoar klasične filologije. Številni raziskovalci opozarjajo, da preučevanje vplivov, citatov in aluzij v antični književnosti tvori jedro "tradicionalne « filološke metode. ${ }^{34}$ Za razumevanju koncepta intertekstualnosti v klasični filologiji zato nekateri raziskovalci izpostavljajo predvsem vpliv Bahtina, Kristeve in Barthesa, ${ }^{35}$ Schmitz pa med vplivnimi teoretiki dodaja še Riffaterra in Genetta, ${ }^{36}$ vsem raziskovalcem pa je skupno, da ločujejo koncepciji intertekstualnosti in vpliva oz. aluzije. ${ }^{37}$ Baraz in van der Berg tako na primer ugotavljata: »Rezultat kritične razprave o intertekstualnosti vključuje novo vrednotenje prodornosti in produktivnosti imitacije, priznanje, da si referenca tradicijo hkrati lasti ter ji nasprotuje, in sprejetje, da avtorji $\mathrm{z}$ aluzijami interpretirajo svoje predhodnike ter hkrati postavljajo metakritične trditve o svojem lastnem besedilu« ${ }^{38}$ Ugotovitev je še toliko bolj pomenljiva, če upoštevamo vpliv strukturalističnega pojmovanja razumevanja literarnih besedil na filologijo: da torej "pomen nastaja šele znotraj sistema« oz. v samem razmerju med besedili. ${ }^{39}$ Tradicionalna klasična filologija je $\mathrm{v}$ svoji pestri zgodovini, podobno kot druge literarne vede ${ }^{40}$ medbesedilne navezave razlagala $s$ klasičnim modelom vpliva, kjer torej določeno literarno delo neposredno vpliva na avtorja besedila. Ta vpliv je seveda singularen (gre torej za vpliv točno določenega oziroma točno

30 Allen, Intertextuality.

31 e.g. Harris, Art History, 170-171; za razumevanje strukturalizma v arhitekturi in urbanizmu teoriji glej tudi Zabel, »Roland Barthes in urbanizem«.

32 e.g. Worton, Still, Intertextuality: Theories and practices.

33 e.g. Klein, Intertextuality in Western Art Music.

34 Fowler, »On the Shoulders of Giants: Intertextuality and Classical Studies«; Schmitz, Modern Literary Theory; Martin, »Intertextuality«; Baraz, van der Berg, »Intertextuality: Introduction«.

35 Martin, »Intertextuality«; Baraz, van der Berg, »Intertextuality«.

36 Fowler, "On the Shoulders«, med drugim opozarja tudi na znanega italjanskega filologa Gian Biagia Conteja.

37 Za kratek pregled diskusije glede pojmovanja in razumevanja aluzije, interteksta, reference itd. glej Baraz, van der Berg, »Intertextuality«, 2-3. Za razlikovanje med intertekstualnostjo, aluzijo in tradicionalnimi pristopi glej tudi Hinds, Allusion and Intertext.

38 Baraz, van der Berg, »Intertextuality«, 3.

39 Fowler, »On the Shoulders«, 14-15.

40 Tradicionalno pojmovanje vpliva je namreč zaznamovalo veliko večino literarnovednih disciplin (cf. Virk, Primerjalna književnost na prelomu tisočletja). 
določenih del), predstavlja poseben vidik literarnega besedila, za razumevanje ni bistven in seveda ni univerzalna značilnost vseh literarnih del. Ideja intertekstualnosti pa je s tem tradicionalnim pojmovanjem skoraj povsem prekinila. Pozornost se je iz enosmernega vpliva na avtorja preusmerila na ne-avtorski sistem tekstov, ki je univerzalen in mnogovrsten, teksti so v neprestanem in dinamičnem odnosu, prav to pa je bistvenega pomena za razumevanje literarnih del. Intertekstualne navezave tako predstavljajo glavno lastnost vsakega literarnega besedila oziroma kar same strukture jezika kot takega. ${ }^{41}$

\section{INTERTEKSTUALNOST V EVRIPIDOVEM ORESTU}

Da je intertekstualnost ena izmed pomembnejših lastnosti Evripidove tragedije Orest, nam nenazadnje pove dejstvo, da je Ruth Scodel ${ }^{42}$ v svojem učbeniškem pregledu starogrških tragedij uvrstila članek F. Zeitlin z naslovom The Closet of Masks: Role-Playing and Myth-making in the Orestes of Euripides, ki se ukvarja prav z intertekstualnostjo, med najpomembnejše študije o tej tragediji. Pred kratkim pa je o intertekstualnosti in metafikcijskih oz. metapoetičnih momentih Evripidove tragiške dejavnosti obsežno monografijo objavila tudi Isabelle Torrance. ${ }^{43} \mathrm{Na}$ tem mestu bom torej najprej spregovorili o nekaterih intertekstualnih značilnostih Oresta, nato pa še o konsekvencah intertekstualnosti za interpretacijo te antične tragedije. Med najpomembnejšimi literarnimi besedili, na katera se intertekstualno navezuje Evripidov Orest, je seveda tragedija, ki obravnava isto tematiko, tj. Ajshilova Oresteja.$^{44}$ Evripidovega Oresta lahko razumemo kot »zapleten skupek strukturalnih variacij in obratov Oresteje« z jasnimi intertekstualnimi navezavami na Evmenide, zanikanjem Prinašalk pitnih darov ter predelavo Agamemnona. ${ }^{45}$ Že v Evmenidah je opazen specifičen način, na katerega Evripid spreobrača obravnavano tematiko. V Eum. stoji Orest z Apolonom, ki mu prisega, kako ga bo branil, okrog njega pa so speče Erinije (glej predvsem Eum. 63-93), Noč je tista, ki prinaša blaznost (321-3), Klitajmestrin duh zbudi speče Erinije (94-116) in Apolon jih prežene. V Evripidovem Orestu je situacija povsem nasprotna. Tu je Orest tisti, ki spi, okrog njega pa je zbor budnih žensk, dobronamernih in ne zlih Erinij, Noč je tista, ki mu prinaša miren spanec (Or. 174-7), zbor žensk zbudi

\footnotetext{
41 Fowler, "On the Shoulders «, 14-15.

42 Scodel, An Introduction to Greek Tragedy.

43 Torrance, Metapoetry in Euripides.

44 Tragedija Orest je bila najverjetneje uprizorjena leta 408 pr. Kr., torej proti koncu Evripidovega življenja (Scodel, Introduction, 174). Ajshilova Oresteja pa je bila najverjetneje uprizorjena 1. 458 pr. Kr. Ker naj bi se Evripid rodil l. 48o, je mogoče, da je originalno uprizoritev Oresteje tudi videl. A ker je med uprizoritijo obeh tragedij minilo petdeset let, večina gledalcev originalne izvedbe verjetno ni videla. Torrance zato poudarja ugibanja nekaterih raziskovalcev, da naj bi bila Ajshilova Oresteja ponovno uprizorjena okoli leta 420 pr. Kr., najverjetneje v sklopu malih, morda celo velikih Dionizijev (Torrance, Metapoetry in Euripides, 13).

45 Torrance, Metapoetry in Euripides, 47.
} 
Oresta in Elektra je tista, ki jih prežene oziroma utiša (179). Še več, Elektra direktno posnema Apolonove besede, ko pravi, da ne bo zapustila Oresta. Če

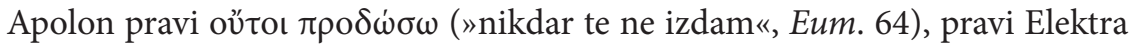

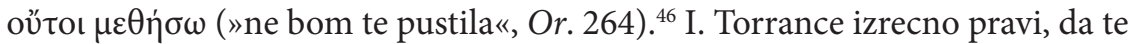
zelo očitne intertekstualne navezave na samem začetku tragedije gledalce namerno opozarjajo na odnos, ki ga ima Evripidova tragedija Orest z Ajshilovo Orestejo. ${ }^{47}$ Druge podobnosti med tragedijama je mogoče najti še v primerjavi Helene in Klitajmestre, ki sta po mnenju F. Zeitlin obe osrednja lika okrog katerih se suče dogajanje, v primerjavi Orestovega zagovora in Apolonovega zagovora Oresta v Evmenidah, potem je tu podobnost Orestovega zagovora (552-6) v katerem trdi, da je oče kot sejalec semena pravi roditelj otroka ter znane Apolonove trditve: »Roditelj plodi, ona brst gosti / in ga ohrani, če ga ne uniči ...« (Eum. 658-66). Tudi bakle, ki jih omenja zbor (1543) je mogoče najdi pri Ajshilu na samem koncu Oresteje (Eum. 1040-44). ${ }^{48}$ Seveda je mogoče precej povezav najti tudi z ostalima dvema tragedijama edine ohranjene trilogije, torej pri Agamemnonu in Prinašalkah pitnih darov. Najprej je mogoče nekatere podobnosti opaziti pri liku frigijskega sužnja (Or. 1369-535) in pa služabnika v Prinašalkah (875-86). Omeniti velja tudi glavo Gorgone, ki jo Wright interpretira kot vpliv neohranjene Evripidove tragedije Andromeda, ${ }^{49}$ a je hkrati moč najti tudi povezavo med Perzejem in Orestom (za katero Wright trdi, da ne obstaja) v Prinašalkah pitnih darov in sicer na dveh mestih: 831-7 ter 1048-9 (»V prsih naj ti bije / Perzejevo srce. / Opravi lepo delo / za svoje drage pod zemljo in na njej. / Zloveščo Gorgono v hiši / udari s krvavo pogubo; / zločinca pa glej v oči, ko ga uničiš« ter »Glej te mračne ženske, kot Grogone, / odete v sivo, v gručo s kačami, / spletene.«). Drugo povezavo z Gorgono je mogoče najti v Evripidovi tragediji Elektra, kjer se pogosto pojavlja na ščitu Ahila. ${ }^{50}$ Prisotne so podobnosti med Helenino željo po odnašanju pitnih darov na Klitajmestrin grob v Orestu in pa začetkom Prinašalk pitnih darov, ko Elektra odnaša daritve na Agamemnonov grob (celo daritve so identične). Takoj za tem Elektra prosi Oresta, naj položi svojo nogo na tla (233: »bi na tla si nogo želel položiti «), s čimer opomni na sled, po kateri je v Prinašalkah pitnih darov prepoznala Oresta. Tu je tudi podobnost Elektrinega govora iz Prinašalk (»daj mi, da bom od svoje matere / razsodnejša, pobožnejša v ravnanju «, 140-41) Orestovemu prigovarjanju (Or. 251-52: "poskrbi da drugačna boš, / ne kot te hudobne ženske [tj. Tindarejeve hčerke] «). Tudi napad Erinij v Orestu je podoben napadu Erinij v Prinašalkah pitnih darov. Ko na

46 Podobnost je mogoče najti tudi s tragedijo Prinašalke pitnih darov, kjer Orest pravi: »jaz vem,

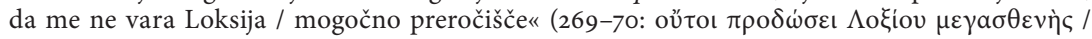
$\chi \rho \eta \sigma \mu \grave{s})$.

47 Torrance, Metapoetry in Euripides, 48.

48 Za podrobnejšo razlago pomena luči v Oresteji in Orestu glej Torrance, Metapoetry in Euripides, 51, 56-57.

49 Wright, »Enter a Phrygian«.

50 Zeitlin, "Closet of Masks«, 317. 
sceno stopi Tindarej, Oresta obtoži z »materomorilsko kačo« (ó $\mu \eta \tau \rho o \varphi o ́ v \tau \eta \varsigma ~$

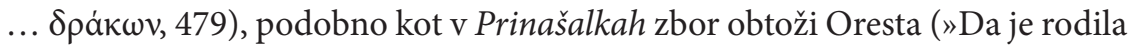
kačo ...«, 527). Precej intertekstualnih navezav je opaziti tudi pri primerjavi s prvo tragedijo trilogije Agamemnon. Že primerjava obeh likov, Helene in Klitajmestre, pokaže nekatere podobnosti: njuna povezava s Tindarejem, njuna prevara ter spletkarstvo, njuno prešuštvovanje. ${ }^{51}$ Prav Orestova odločitev, da ubije Heleno, je podobna njegovemu umoru Klitajmestre in je ponovitev istega dejanja. ${ }^{52}$ Nekatere podobnosti je mogoče opaziti tudi med frigijskim sužnjem in Kasandro ${ }^{53}$ iz tragedije Agamemnon, saj je suženj nekakšna obrnjena podoba Kasandre. Če je trojanska princesa videla prihodnost, preden je vstopila v hišo, in že vnaprej napovedala smrt, je frigijski suženj prišel iz hiše po opravljenem dejanju, da bi poročal o tem, kar se je zgodilo, česar pa sam ne razume. V Orestu Agamemnonov protipol predstavlja Menelaj, ki je opisan kot spreten politik in spletkar, oba se vrneta s partnerico, vendar Agamemnon s priležnico, Menelaj z ženo; Agamemnon je svojo hčer ubil, Menelaj jo bo poskušal rešiti. Opaziti je mogoče še nekatere podobnosti z Agamemnonom, na primer Orestovo hvaljenje Elektrine moškosti (1204-6: »Moško srce imaš, / pa čeprav tvoje telo je žensko«) z govorom glasnika o Klitajmestri (Ag. 10-1: »to veli mi ženska, / možatih misli«). Vendar pa, kot ugotavlja I. Torrance, Elektra prej kot Klitajmestro posnema Agamemnona in njegovo žrtvovanje Ifigenije. ${ }^{54}$ Elektra je namreč tista, ki predlaga ugrabitev Helene in to podkrepi z bese-

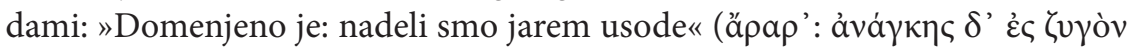

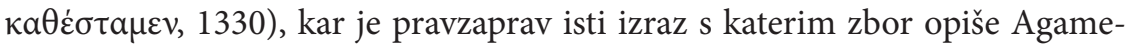
mnonovo žrtvovanje Ifigenije (»nato se je podvrgel jarmu nujnosti / ảvá $\gamma \kappa a \varsigma$

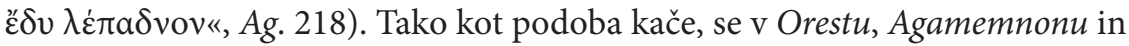
Prinašalkah pitnih darov pojavljata tudi podobi leva in mreže ( $\mathrm{Ag}$. 358, 827, 1375; Cho. 938, 999, 1000; Or. 1315, 1401-2, 1421). ${ }^{55}$ Najti je mogoče tudi podobnost med smrtnim krikom Helene in odgovorom zbora v Orestu (1296-8) ter Agamemnovim smrtnim krikom in odgovorom zbora (Ag. 1343-5).

Zakaj torej navezava na Orestejo? Po mnenju F. Zeitlin se Evripid v tragediji Orest zavestno in intertekstualno sklicuje na trojanski mit. Orestova odločitev, da umori Heleno, ni po njenem prepričanju nič drugega kot ponavljanje

51 Torrance, Metapoetry in Euripides, 52, je odkrila celo povezavo med Orestovim prepričanjem, da bo Helena uživala ob njegovem samomoru (Or. 1122: »da navzven se bo jokala, a se pri sebi veselila«), in poročilom dojilje iz Prinašalk pitnih darov, ko pravi: »si je nadela jezno žalosten / pogled, pri sebi pa smejé slavila« (737-8).

52 Cf. Zeitlin, »Closet of Masks«.

53 Pravzaprav Zeitlinova precej pozornosti nameni vlogi frigijskega sužnja, ki po njenem mnenju predstavlja krizo tradicionalnih partiarhalnih vrednot, ki jim želi slediti Orestes, družba pa jih ne priznava več. Zeitlinova meni, da tragedijo zaznamuje prav umanjkanje vsakršnega očetovskega lika: odsoten je Agamemnon, odsoten je Apolon, podporo mu odreče Menelaj. Edina prava očetovska figura v celotne tragediji tako postane Tindarej, ki pa Orestu ter njegovim argumentom odkrito nasprotuje (Zeitlin, »Closet of Masks«, 327-333; cf. Chong-Gossard, Gender and Communication, 121-125).

54 Cf. Torrance, Metapoetry in Euripides, 54.

55 Ibid. 
istega dejanja, ki se je zgodilo že prej, torej umora Klitajmestre, prav umor Klitajmestre pa je pogojem z umorom Agamemnona. Če primerjamo podobo Troje v vseh treh tragedijah Oresteje, lahko ugotovimo, da je dogajalni čas zelo natančno določen: v Agamemnonu je Troja ravnokar padla, v Prinašalkah pitnih darov je Troja zgolj spomin, ki se kaže v zboru Trojank, v Evmenidah pa je Troja večinoma že pozabljena in je prešla, če smemo tako reči, v kolektivni spomin. Tudi dogajanje je zgrajeno jasno in očitno, eno dejanje vodi k druge$\mathrm{mu}$, dokler se na samem koncu Orest ne znajde pred sodiščem. V nasprotju z Orestejo v Orestu Elektra v uvodnem spevu opiše družinsko drevo do Tantala in Pelopsa in s tem poveže celotno družinsko tragedijo v krožnost in nujnost ponavljanja (Or. 1-83). Troja in trojanski mit v Orestu igrata torej ključno vlogo tako v vsebinskem kot v simbolnem smislu, saj Troja Orestu predstavlja »model herojskega delovanja«, patriarhalnih vrednot in obveze kaznovanja prešuštev. ${ }^{56}$

$\mathrm{V}$ povezavi s trojanskim ciklom velja omeniti tudi nekatere podobnosti Evripidove tragedije in Odiseje (na katero celo opozori Frigijski suženj na 1404). V Odiseji na primer Telemah obišče Sparto, kjer praznujejo dvojno poroko brata in sestre (4.3-4), ena izmed žena pa je tudi Hermiona. Z obljubo dvojne poroke Oresta in Elektre, torej brata in sestre se konča tudi Orest. $\mathrm{Na}$ omembo Odiseja v pogovoru s frigijskim sužnjem smo že opozorili, treba pa je opozoriti še na primerjavo med Piladom in Hektorjem ter Ajaksom (1579-80), ki jo izpostavi Frigijski suženj, ter na primerjavo med Odisejevo zvijačnostjo in zvijačnostjo Pilada (1403-6), ki si je zamislil načrt za umor Helene in Hermione.

Poleg zgoraj naštetih intertekstualnih navezav je nekatere podobnosti mogoče prepoznati tudi med Orestom in Medejo. Primerjava s tragedijo Medeja pokaže nekatere vsebinske podobnosti: podobna je na primer situacija glavnega lika, ko ne more nikamor pobegniti in se v obupu odloči za umor, podobna je tematika izdaje ljubljene osebe (v Orestu Menelaja) ter odločitev o uboju njegovih najbližjih. Kot direktno posnemanje lahko razumemo sceno, v kateri glavni lik stoji na strehi ter noče vrniti ugrabljenih otrok, kar velja tako za Medejo kot za Oresta. Najti je mogoče tudi podobnost med smrtnim krikom Medeje in pa smrtnim krikom Helene, ki smo ga primerjali z Agamemnonovim smrtnik krikom že zgoraj. ${ }^{57}$ Omeniti velja vsaj še eno (prav tako Evripidovo) tragedijo, ki jo je mogoče primerjati z Orestom: Ifigenijo pri Tavrijcih. Če ima Orestes v Ifigeniji pri Tavrijcih pravzaprav pozitivno in javno družbeno vlogo, saj v Atene po naročilu Apolona pripelje Artemidin kult, je njegova vloga v Orestu obratna, saj se poskuša Orest maščevati Menelaju iz povsem zasebnih razlogov. Podobnost je mogoče najti tudi med prizorom Oresta in Pilada, ki v obeh tragedijah poskušata žrtvovati sebe za dobrobit drugega oziroma vsaj v 
oporo drugemu. Pravzaprav je motiv samožrtvovanja prisoten tako v Ifigeniji pri Tavrijcih kot v Orestu (ne zgolj pri Piladu in Orestu, ampak tudi pri Ifigeniji in Elektri). A če je samožrtvovanje v Ifigeniji pri Tavrijcih vsem akterjem pravzaprav zagotovilo rešitev, je vloga samožrtvovanja v Orestu drugačna, saj je bila možnost herojskega samo-žrtvovanja vsem dejansko ponujena, a so se raje odločili za maščevanje in prevaro.

Bolj zanimiv kot zgolj naštevanje vseh mogočih vzporednic je pravzaprav razmislek o tem, kakšne ugotovitve sploh prinese raziskovanje intertekstualnosti v Evripidovem Orestu. F. Zeitlin v že omenjenem članku na primer ugotavlja, da je intertekstualnost v Orestu odraz izčrpanja tragedije kot umetniške forme - v Orestu je tako mogoče opaziti samozavedanje in refleksijo bogate tragiške tradicije, ki prav s tem dosega konec svojega »organskega razvoja «. ${ }^{58}$ Zakaj? Prav zaradi svoje intertekstualnosti. Tragedija Orest je bogato intertekstualno delo oziroma je, kot pravi F. Zeitlin "palimpsestičen tekst, v katerem lahko dešifriramo plast pod drugo plastjo, vsaka pa ima svoj prispevek « ${ }^{59} \mathrm{k}$ tvorjenju pomena in interpretaciji besedila. Še več, tragedija »spodbuja razkroj samega jezika, deformira leksična sredstva, sprevrača odnose, samosvoje in naključno ločuje označenca od označevalca... «. ${ }^{60}$ Prav tako je mogoče v tragediji opaziti razhajanje med mitom (oz. arhaično družbo) ter sodobnejšo družbo oz. realnostjo dogajalnega časa drame. ${ }^{61} \mathrm{~F}$. Zeitlin na primer pravi: »Orest je gotovo primer modernega človeka v svoji bolezni in nestabilnosti duha, vendar pa je prav tako tudi arhaičen človek, ki se spogleduje $\mathrm{z}$ arhaičnimi vidiki mita in vrednot, da bi se odrešil. Tako sam postane tvorec mita v svetu, ki je sam mit zapustil «. ${ }^{62}$ Orest je tako lik, ki je »prebral besedila « ${ }^{63}$, ki torej pozna mitsko zgodovino in jo poskuša obnoviti v neprestanem aktu ponavljanja in obnavljanja herojskih dejanj.

Tragedija Orest je torej »mimesis mimeseos «, tragedija, v kateri prvič naletimo na "povsem samo-reflektirajoče umetniško delo", torej »umetnost v procesu reflektiranja same umetnosti «. ${ }^{64} \mathrm{~V}$ tem Evripidovem delu si torej ne nasprotujeta zgolj mit in realnost, temveč tudi mit in fikcija oz. literatura. »V odsotnosti Apolona [...] se zdi, da mit ustvarja fikcijo, da mitski fakt nadomesti fikcija, ki je nasprotna mitskemu faktu «, ${ }^{65}$ pravi Zeitlinova. Mit Orestu ne dovoljuje, da bi kadarkoli ubil Heleno, a vendar se zdi, da je tragedija to fiktivno možnost dopustila, vsaj do samega konca, ko na oder le stopi deus ex machina Apolon. Z aluzijami in sklicevanji na druga besedila, ki pravzaprav ustvarjajo sam pomen Oresta, tragedija dosega novo »literarno zavest«, sam

\footnotetext{
58 Zeitlin, »Closet of Masks«, 309-311.

59 Ibid., 314.

60 Ibid., 319 .

61 To med drugim opažajo F. Zeitlin, J.R. Porter in R. Scodel.

62 Zeitlin, "Closet of Masks«, 331.

63 Ibid.

64 Ibid., 337.

65 Ibid., 310
} 


\section{status literarnosti. ${ }^{66}$}

Mnenje raziskovalcev glede intertekstualnih navezav v Evripidovi tragediji Orest se torej precej približuje teorijam intertekstualnosti, ki smo jih opisali zgoraj in ki v temeljih izhajajo iz francoskega strukturalizma ter post-strukturalizma. Ideja Zeitlinove o palimpsestičnem tekstu je seveda zelo blizu razumevanju inter-teksta pri vseh zgoraj opisanih teorijah intertekstualnosti. Ideja o tragediji, ki je prvič postala literatura, torej "povsem samo-reflektirajoče umetniško delo« oz. »umetnost v procesu reflektiranja same umetnosti «, ${ }^{67}$ je posebej blizu pojmovanju literarnosti pri Riffaterru in Barthesu. Po mnenju F. Zeitlin je Orest zaprta literarna struktura, ki svoj pomen dobiva iz referiranja in sklicevanj na druga literarna besedila. Je zgolj znak, katerega referent je le nov znak, pomene pa tragedija dobiva v neprestani igri in odnosu do drugih znakov oziroma besedil.

\section{INTERTEKSTUALNOST, DA ALI NE?}

Kot smo videli, je po mnenju F. Zeitlin tragedija Orest bistveno intertekstualna. A intertekstualnost se ne odraža zgolj v aluzijah in navezavah na druga besedila, temveč, če lahko tako rečemo, v ontološkem modusu načina obstoja te Evripidove tragedije. Pa je to res? Lahko brez pomislekov sprejmemo prepričanje F. Zeitlin? V nadaljevanju bom podal tri ugovore, ki nasprotujejo tej tezi. Pri tem bom sledil izjemno enostavnemu, vendar pa nadvse pomembnemu in večkrat spregledanemu dejstvu: namreč, da je pri interpretaciji tragedije potrebno upoštevati prvotni recepcijski kontekst ter horizont pričakovanja primarnih sprejemnikov. ${ }^{6} \mathrm{Na}$ podlagi recepcijske teorije se bom najprej posvetil vplivu širšega konteksta na interpretacijo Oresta kot intertekstualnega literarnega dela. Pri tem bom zagovarjal, da prav ritualni kontekst tragedije, ki so ga obiskovalci uprizoritve Oresta nedvomno poznali in razumeli, nasprotuje intertekstualni vlogi tragedije, kot jo razlaga F. Zeitlin. Nato bom razpravljal o vlogi jezika v ter poskušal pokazati, da je bila narava tragiškega jezika drugačna od strukturalističnega pojmovanja jezika kot sistema znakov. Tretjič,

66 Ibid., 312. Razumevanju literarnosti je blizu tudi koncept metapoetike v Orestu, ki je blizu konceptu metafikcijske književnosti. I. Torrance našteje primere "samozavedajočega se metapoetskega uvida « ter bogate intermedialnosti: tako na primer zbor opozarja na ne-mitsko dogajanje (1503: "novost sledi novostmi«), ali na začetku drame, ko Orest sprašuje Elektro (239: »kaj je novega, povej«), ta pa mu odgovori, da je v mesto prispel Menelaj - dogodek, ki najverjetneje ne sledi nobeni izmed ustaljenih mitskih različic in hkrati napoveduje presenetljiv iztek tragedije. Celo Elektrin vzklik (128-29: "Ste videli kako od las si zgolj konice je odstrigla, / da ohranila bi lepoto? «) je po mnenju I. Torrance pravzaprav metafikcijski nagovor občinstvu (Torrance, Metapoetry in Euripides, 60).

67 Zeitlin, »Closet of Masks«, 337.

68 Izraz sprejemnik temelji na Jakobsonovem komunikacijskem modelu, ki ga v grobem sestavljajo sporočevalec, sporočilo in sprejemnik. V primeru tragedije Orest je bil torej primarni sprejemnik obiskovalec Dionizovega gledališča, v katerem je bila tragedija uprizorjena. Cf. Mastronarde, The Art of Euripides: Dramatic Technique and Social Context, 47. 
razpravljal bom o ontologiji literarnega dela in ontologiji ustne tradicije ter poskušal pokazati, da prav ne-literaren kontekst in ne-literarna tradicija nasprotujeta ideji intertekstualnosti, ki se v svojem razumevanju bistveno opira na razumevanje literature kot zapisanega teksta.

\section{a) Tragedija kot performance}

Ko govorimo o intertekstualnosti v Evripidovem Orestu je torej potrebno upoštevati tudi širši zgodovinski kontekst tragedije. Če upoštevamo izvorni kontekst tragedije, izvorni kontekst njene recepcije ter horizont pričakovanja sprejemnikov, ne moremo mimo dejstva, da je bila tragedija uprizorjena v sklopu rituala. Mastronarde ugotavlja, da so ta kontekst določali predvem umeščenost v program tragiškega tekmovanja, kostumi in maske igralcev, forma jezika ter jambski trimeter, mitološka identiteta osrednjih vlog, prisotnost zbora in flavtista etc. ${ }^{69}$

Dejstvo je torej, da so tragedije uprizarjali v sklopu različnih praznovanj in da so jih tudi gledalci razumeli v tem kontekstu. Ne da bi se spuščali v razpravo o izvoru same tragedije, lahko potrdimo, da je bil tragedija nedvomno del teh ritualov. ${ }^{70}$ Atenska tragedija, ki se je izvajala v sklopu malih ali velikih Dionizij, je bila tudi v petem stoletju del ritualnega obreda, posvečenega Dionizovemu kultu. ${ }^{71}$ In v sklopu velikih Dionizij so 1.408 pr. Kr. uprizorili tudi Evripidovega Oresta. ${ }^{72}$

Ritualni kontekst tragedije je torej pomemben za njeno razumevanje, še toliko bolj, če pomislimo, da so jo kot tako skoraj gotovo razumeli tudi njeni primarni sprejemniki, torej gledalci in obiskovalci velikih Dionizij. Kaj torej to pomeni za samo intertekstualnost Oresta? F. Zeitlin ugotavlja, da je pojav intertekstualnosti v Orestu povezan s prehodom iz mita v fikcijo oziroma literaturo, pri čemer sledi strukturalistični tradiciji. Takšen koncept literature implicira njen samozadosten in avtonomen status in je s tem gotovo bližje

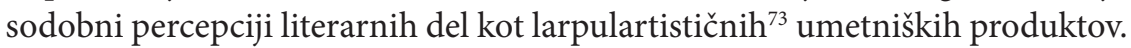
Vendar, so tragedijo Orest na tak način razumeli tudi njeni primarni sprejemniki?

Kot sem pokazal v prejšnjem poglavju, je Evripidov Orest poln različnih aluzij. O vseh odkritih in neodkritih aluzijah je seveda mogoče razpravljati, a nekatere izmed njih, vsaj na primer navezava na Ajshilovo Orestejo, so jasno prisotne. Vendar pa je zaključek, da ta prisotnost medbesedilnih navezav kaže na prehod tragedije iz mita $\mathrm{v}$ literaturo, da se je forma tragedije izčrpala in

69 Mastronarde, The Art of Euripides, 50.

$70 \mathrm{O}$ neposrednih ritualnih elementih tragedije glej Easterling, »Tragedy and Ritual. Cry 'Woe, Woe', but May the Good Prevail! «.

71 Sourvinou-Ingwood, Tragedy and Athenian Drama; Senegačnik, »Klasična atiška tragedija

72 Wright, Euripides: Orestes, 9.

73 Tako si namreč lahko razlagamo trditev F. Zeitlin, da je tragedija Orest pravzaprav »umetnost v procesu reflektiranja same umetnosti« (Zeitlin, „Closet of Masks«, 310). 
da je Orest postal samo-reflektirajoče, samozadostno in avtonomno umetniško delo, ki svoj pomen dobiva zgolj iz razmerja do ostalih besedil, pretiran. Orest je najprej in predvsem tragedija, ki je bila uprizorjena v sklopu velikih Dionizijev in ritualne tradicije in ki so jo kot tako sprejeli ter razumeli tudi obiskovalci Dionizovega gledališča.

Mastronarde na primer ugotavlja, da je potrebno tragedijo, še posebej pa tragedijo v 5. stol. pr. Kr., razumeti kot razvijajočo se zvrst, ki jo odlikuje prav eksperimentalnost in inovativnost. Pri tem navaja nekaj precej prepričljivih argumentov, ki potrjujejo tezo, da se je tragedija pravzaprav ves čas spreminjala ter da ne moremo določiti »klasične« oz. tipične tragične forme. Tako na primer opozarja na profesionalizacijo poklica pisca tragedij ter na relativno avtonomnost gledališča druge polovice petega stoletja, ki sta nedvomno omogočala določen prostor za inovacije in spremembe. ${ }^{74} \mathrm{~A}$ še bolj pomembno se zdi njegovo opozorilo na agonalno tradicijo grške kulture ter seveda na agonalnost same tragedije. ${ }^{75}$ Po njegovem prepričanju sta bila ravno tekmovanje ter borba za pozornost gledalcev ena izmed poglavitnih gonil inovacij v tragediji, v spreminjanju tragiškega jezika, zgradbi tragedije ter v spremembah same scenografije. ${ }^{76}$

Kar se torej tiče intertekstualnih navezav oziroma aluzij, jih lahko razumemo prav kot eno izmed takšnih inovacij, ki same po sebi ne spreminjajo narave same tragedije. ${ }^{77}$ Tragedija je zaradi recepcijskega koncepta pripadal ritualu ter je bila performativno vpeta v kontekst velikih Dionizijev. Njena ontološka in hermenevtična struktura se torej z aluzijami na druga literarna besedila ni bistveno spremenila in Orest ni s tem postal nič bolj literaren. S stališča recepcije je potrebno intertekstualnost razumeti predvsem kot novo in inovativno tehniko v sklopu agona velikih Dionizij. Sama tragedija hermenevtično torej še vedno ostaja del tega konteksta.

\section{b) Vloga jezika ni strukturalistična}

Naslednja točka, ki jo je potrebno natančneje razmisliti, ko razpravljamo o intertekstualnosti v tragediji Orest, je prav vloga jezika. Kot smo videli v kratkem zgodovinskem pregledu, je bistvenega pomena za poznejši koncept intertekstualnost prav strukturalistično razumevanje jezika. ${ }^{78}$ Strukturalizem pojmuje jezik kot sistem jezikovnih znakov, ki so sestavljeni iz označenca in označevalca, slednji pa svoj pomen dobijo prav iz medsebojnega razmerja $\mathrm{v}$

\footnotetext{
74 Mastronarde, The Art of Euripides, 48.

75 Ta argument se zdi še toliko prepričljivejši, ko pomislimo, da je bila agonalnost tragedije bistevno povezana $\mathrm{z}$ njenim ritualnim kontekstom, o katerem bomo razpravljali v nadaljevanju (o agonalnosti v tragediji glej Senegačnik, "Klasična atiška tragedija«, 85-86, o agonalnosti v grški družbi pa Vernant, Začetki grške misli).

76 Mastronarde, The Art of Euripides, 44-54.

77 Mastronarde, The Art of Euripides, 83-85.

78 Torej predvsem za intertekstualnost pri Genettu, Riffatteru, Barthesu etc.
} 
sistemu. Jezik je tako bistveno nereferencialen in zaprt sistem, ki nikoli ne referira na izven-jezikovno realnost. Nekaj podobnega o tragediji Orest trdi tudi F. Zeitlin, ko zapiše, da tragedija »spodbuja razkroj samega jezika, deformira leksična sredstva, sprevrača odnose, samosvoje in naključno ločuje označenca od označevalca ... «. ${ }^{79}$ Mnenje o naravi literarnega in pesniškega jezika se med raziskovalci seveda bistveno razlikuje. Če nekateri sledijo strukturalističnim predpostavkam, pa drugi prepričljivo dokazujejo, da literatura na splošno ${ }^{80}$ ali pa vsaj pesniški jezik ${ }^{81}$ nikakor ne ustrezata strukturalističnemu pojmovanju jezika, predvsem pa ne njegovi ne-referencialnosti.

Manfred Frank se tako na primer nasloni na Schleiermacherjevo ${ }^{82}$ razumevanje jezika in ga razume kot »dvojno označen« jezikovni izraz oziroma govor. ${ }^{83}$ Tako je po eni strani vsak jezik gramatičen in univerzalen sistem, ki ima svoja sintaktična in semantična pravila, po drugi strani pa je jezik vedno tudi govorjen jezik, torej jezik kot partikularna realizacija sistema jezika. Govorjeni jezik oziroma govor reproducira in potrjuje gramatični sistem, hkrati pa ves čas v njem proizvaja nekaj novega in s tem spreminja tudi samo univerzalnost jezika. ${ }^{84}$ Jezik je torej »individualno obče «, ${ }^{85}$ je univerzalno gramatično pravilo vseh njegovih uporabnikov (torej jezik kot sistem) in hkrati njegova individualna realizacija. Prav ta individualna realizacija jezika, torej sam govor, pa je tisto, kar tvori univerzalen jezikovni sistem. Frank potrdi Saussurovo prepričanje o jeziku kot »družbenem dogovoru «, ${ }^{86}$ vendar pa na podlagi tega prepričanja zaključuje, da je univerzalnost jezika kot sistema odprta za individualno govorno dejanje. Še več, individualna manifestacija jezika tvori in spreminja njegovo univerzalno strukturo. Družbena vloga jezika torej omogoča realizacijo individualnega govora v občem sistemu jezika.

Frank ugotavlja, da je pesniški jezik oziroma "poetični govor« najbolj »smisel ustvarjajoča potenca in je torej najmočnejši individualni vpliv na občo strukturo jezika. ${ }^{87}$ Ker pesniški jezik uporablja nekonvencionalno metaforiko oziroma različna pesniška sredstva, se s tem odmika od univerzalne gramatične strukture in hkrati vanjo vnaša nove individualne pomene. »Poetični govorec« torej v jezik »tako rekoč vsili svojo $([\ldots])$ individualnost « ${ }^{88}$

79 Zeitlin, »Closet of Masks«, 319.

80 Glej na primer Snoj, O literaturi drugače.

81 Glej na primer Bonnefoy, Odmakniti pogled od knjige.

82 Za pregled Schleiermacherjeve filozofije jezika glej na primer Crouter, Friedrich Schleiermacher, 195-206.

83 Frank, »Besedilo in njegov slog«, 216.

84 Ta dvojnost jezika, torej razlika med govorom (parole) in jezikom (langue), strukturalistom ni neznana, o njej pa smo razpravljali že pri Saussurju. Vendar pa se je Saussure izrazito opredelil za preučevanje jezika kot sistema in ne njegove manifestacije, torej govora, s tem pa je vplival na vse kasnejše strukturaliste in poststrukturaliste. Manfred Frank na tem mestu torej zabrisuje dihotomijo med govorom (parole) in jezikom (langue) in poudarja njuno medsebojno odvisnost.

85 Frank, »Besedilo in njegov slog«, 220.

86 Saussure izrecno trdi, da je razmerje med označencem in označevalcem povsem podvrženo družbenemu dogovoru.

87 Frank, »Besedilo in njegov slog «, 220-221.

88 Frank, »Besedilo in njegov slog «, 221-222. 
Slednji svojo individualno in svobodno misel vpiše v univerzalni sistem jezika tako, da ga prilagodi svoji misli, s tem pa seveda posledično spremeni univerzalno strukturo jezika. Za pesniško besedilo je torej bistvena individualnost uporabe jezika, ali kot pravi Frank, sloga.$^{89}$ Takšna koncepcija jezika upošteva tudi historične in individualne vplive ter spremembe, ki jih v univerzalni sistem jezika vnašajo individualne realizacije govora. $S$ tem pa se jezik, kot ga pojmuje Manfred Frank, razlikuje od strukturalističnega koncepta jezika kot avtonomnega in ne-referencialnega sistema..$^{90}$

Ali jezik torej v tragediji Orest »deluje« na strukturalističen način? Je Evripidov jezik resnično izven-jezikovno nereferencialen? Mastronarde denimo ugotavlja, da se v nekaterih momentih Evripidov jezik razlikuje od starejših tragedov: njegov jezik je na primer »v primerjavi z Ajshilovim « nekoliko »lahkotnejši«, vsebuje več "vsakdanjih", "prozaičnih in kolokvialnih besed «, njegov »trimeter pa je nekoliko razrahljan «. ${ }^{11}$ Ne moremo pa trditi, da Evripidov jezik ni bistveno »tragiški jezik«, saj ohranja »metrum in cezuro«, »besedišče, zaporedje besed in sintaksa se razlikujejo od vsakdanjega govora «, pesnik pa pogosto posega po »metaforah značilnih za visoko poezijo ${ }^{92}$ Vse to potrjuje, da je Evripidov jezik značilno tragiški jezik, ki upošteva določila tragedije kot žanra.

Kot tak je jezik tragedije Orest veliko bližje Frankovemu pojmovanju jezika kot pa strukturalistični nereferencialnosti. Vendar F. Zeitlin zagovarja, da je tragedija Orest izčrpala svojo formo ter iz mita prestopila na področje literature. $S$ stališča jezika bi lahko vzporednice z njeno teorijo našli na primer pri Martinu Heideggru, ki v besedilu z naslovom Kaj je to - filozofija zagovarja tezo, da je pred-metafizična grška filozofija besedo kot $\lambda$ ó ${ }^{\circ} \varsigma$ povezovala $\mathrm{z}$ dejanskim obstojem bivajočega (da je torej beseda razklepala samo bivajoče). ${ }^{93}$ Če nekoliko na silo poskušamo to misel opisati s strukturalističnimi pojmi, bi lahko rekli, da v jezikovnem znaku pred-metafizičnega grškega človeka, delitev na označevalca in označenca ni obstajala: označevalec in označenec sta bila eno in isto, njuna delitev bi lahko pogojno obstajala šele s pojavom metafizike. In prav v ta čas oziroma na to točko prehoda F. Zeitlin umešča Evripidovega Oresta. ${ }^{94}$ A Heideggrovo pojmovanje jezika je povsem drugačno od struktu-

89 Pojem sloga in njegove individualistične implikacije Manfredu Franku predstavljajo pomemben očitek proti strukturalizmu in univerzalističnemu preučevanju literature. Za to glej predvsem Frankovo kritiko Bartesa (Frank, »Kaj je literarno besedilo«).

$90 \mathrm{~V}$ tem smislu lahko razumemo tudi Frankovo razlikovanje med pomenom in smislom jezika. Pomen je tako odvisen od univerzalne gramatične strukture jezika, smisel pa je »nedoločena usedlina, gošča besedila, ki porajajoč smisel, vznika v drugih zavestih (consciences), ki niso zavest "prvotnega bralca" ali "pisca«, in omogoča, da se v besedah odkriva nekaj, kar niso vanje vnesli niti slovar niti gramatika niti avtor in niti (sami) dosedanji bralci« (Frank, »Kaj je literarno besedilo«, 238).

91 Mastronarde, The Art of Euripides, 50.

92 Ibid.

$93 \mathrm{Za}$ Heideggrovo razumevanje govorice glej tudi Heidegger, $\mathrm{Na}$ poti do govorice.

94 Evripid naj bi živel od 1. 480 do 406 pr. Kr., tragedija Orest pa je bila verjetno uprizorjena leta 408 pr. Kr. Heidegger pojav metafizike povezuje s Platonom, ki naj bi se rodil 1. 428/427 ali pa 
ralističnih koncepcij. Tako na primer v predavanjih o Hölderlinu zagovarja, da jezik razkriva bit, ${ }^{95}$ podobno pa ugotavlja tudi za samo grško umetnost. ${ }^{96}$

Upoštevanje narave tragiškega jezika, ki se ju poslužuje Evripid, še potrjuje ugovor proti razumevanju Oresta kot intertekstualnega dela. Sam bi torej zagovarjal, da je struktura in uporaba jezika v tragediji Orest bližje Frankovi koncepciji jezika. Jezik v tragediji je namreč kontekstualno in žanrsko pogojen, kar pomeni, da mora biti tak jezik predvsem izven-jezikovno referencialen. Strukturalistični koncept intertekstualnosti pa predpostavlja prav ne-referencialnost jezika kot avtonomnega in zaprtega sistema znakov. Narava jezika v tragediji Orest pa se temu konceptu ne prilega najbolje.

\section{c) Interteksutalnost v ustnem izročilu}

Pomen ustnega izročila za grško književnost je obsežno in kompleksno vprašanje. Tragedija strogo vzeto ne pripada tradiciji ustnega izročila, a se ji preko performativnosti na nek način približuje. ${ }^{97}$ Čeprav vemo, da so tragedije (vsaj v obdobju helenizma) brali in da so bila dela celo dostopna v atenskem arhivu, ${ }^{98}$ je narava same tragedije seveda precej drugačna od zapisanega besedila. Tragedija se je namreč predvsem uprizarjala, s tem pa je njena vloga precej bližje arhaičnem pesništvu ${ }^{99}$ in ustnemu izročilu, kot pa sodobnemu pojmovanju zapisanega literarnega dela. Če upoštevamo horizont primarnih sprejemnikov, je tako vloga intertekstualnosti v tragediji precej bližje vlogi intertekstualnosti $\mathrm{v}$ ustni tradiciji kot pa na primer vlogi intertekstualnosti $\mathrm{v}$ zapisanih in branih literarnih del.

Nigel Nicholson na primeru Pindarjeve desete ode pokaže na metodološko plodno uporabo koncepta intertekstualnosti pri preučevanju povezav med tem, čemur sam pravi "visoka literatura«, in ustno tradicijo. ${ }^{100}$ A prav na tem mestu se je potrebno ustaviti in natančneje premisliti kakšna je v tem primeru vloga intertekstualnosti. Kakšno je razmerje med Pindarjevo deseto odo in ustno tradicijo? Kako razumemo Pindarjevo poezijo in kako razumemo ustno tradicijo? Ter kakšna je vloga intertekstualnosti? Ker Nicholson pravzaprav ne razložil natančneje, kako sploh razume Pindarjevo poezijo (kot zapisano besedilo, kot izvajano zborovsko pesem, kot del ustne tradicije, ali kot literarno delo?), bom poskusil o vprašanju ustne tradicije in intertekstualnosti razmisliti na drugem primeru. In sicer na primeru, ki ga je kot demonstracijo

1. $424 / 423$ pr. Kr. in umrl 1. 348/347 pr. Kr. Časovno je torej povezava primerna, še posebej če upoštevamo družbene in zgodovinske spremembe, predvsem pa konec Peloponeških vojn 1 . 404 pr. Kr. (Pomeroy, A Brief History; Bratož, Grška zgodovina).

95 Heidegger, Razjasnjenja ob Hölderlinovem pesništvu.

96 Heidegger, »Izvir umetniškega dela«.

97 Cf. Segal, "Song, Ritual, and Commemoration«.

98 Cf. West, »The Early Chronology of Attic Tragedy«.

99 Izvedba je bila namreč pomemben element arhaičnega pesništva (cf. Marinčič, Grška književnost arhaične dobe, npr. 40, 128-29).

100 Nicholson, »Cultural Studies«. 
intertekstualnosti uporabil Genette, namreč razmerje med Uliksesom Jamesa Joyceja, Vergilijevo Eneido in Homerjevo Odisejo. ${ }^{101}$

Kot vemo, je Odiseja nastala v »mračnih stoletjih « kot del ustne epike. Zapisana je bila šele veliko kasneje, v svoji današnji obliki pravzaprav šele v času helenizma, tekom zgodovine pa se je ves čas prenašala kot ustno izročilo. ${ }^{102}$ Med drugim sta bili Iliada in Odiseja pomemben šolski material in načeloma so se oba epa vsi šolajoči se otroci naučili na pamet. ${ }^{103}$ Kako lahko torej Odisejo definiramo kot tekst in kako lahko razumemo njene intertekstualne reference? Ali se je $\mathrm{z}$ rapsodskimi izvajanji in $\mathrm{z}$ rapsodskimi spremembami ter inovacijami vsaka nova izvedba tega Homerskega epa intertekstualno navezovala na vso preteklo ustno tradicijo in na vsako preteklo izvedbo? In ali je bil helenistični zapis in ureditev Iliade prav tako oblika intertekstualnega zapisa novega besedila? Vse te teze se seveda zdijo nevzdržne. Burgess tako opozarja, da je vsak poskus intertekstualnega preučevanja ustne tradicije njeno vlogo povsem neupravičeno poenostavil na raven »teksta «. ${ }^{104} \mathrm{Ob}$ tem opozarja tudi, da se s tem neupravičeno potvarja tudi horizont pričakovanja primarnih sprejemnikov ustne tradicije. ${ }^{105}$

A v nasprotju s tem lahko trdimo, da sta tako Joyceov roman Ulikses kot tudi Eneida intertekstualni besedili, saj sta nastali kot intertekstualna referenca na že obstoječe literarno delo, torej takrat, ko je Odiseja sama že postala literarno delo in ni več pripadala ustni tradiciji. Dejstvo, na katero je opozoril že Schmitz, da velika večina antične literature ustreza Genettovi tezi o transpoziciji, ${ }^{106}$ tako verjetno ni posledica splošne intertekstualnosti antične literature, ampak prej odraža kontekst, v katerem je antična literatura nastajala.

Primerjava ustne tradicije in intertekstualnosti nam odpira vprašanja tudi pri razumevanju intertekstualnosti v tragediji. Ali lahko tragedijo razumemo kot literarno delo? In ali so jo tako razumeli njeni primarni sprejemniki? Kot smo poskušali pokazati zgoraj, tragedija pripada drugačni tradiciji, torej tradiciji rituala. Tudi njena narava je precej bližje ustni tradiciji, saj so se tragedije uprizarjale. Tako se zgoraj našteti argumenti proti razumevanju ustne tradicije kot intertekstualne zdijo primerni tudi za tragedijo. Ali torej trditev o intertekstualnosti Oresta neupravičeno zreducira naravo tragedije na zapisan

\footnotetext{
101 Genette, Palimpsests, 5-7.

102 Cf. Whitmarsh, Starogrška literatura.

103 Freeman, Schools of Hellas, 50.

104 Burgess, »Neoanalysis«.

105 Problematika intertekstualnosti in ontološkega statusa ustne tradiciji je izjemno zanimiva. Še posebej pa se njena relevantnost izkaže, ko pomislimo na danes tako popularno preučevanje drugih, dalj časa trajajočih ustnih tradicij, na primer indijske književnosti (kar velja predvsem za primerjalno književnost). Ali lahko torej ustno književnost preučujemo z metodami, ki jih je razvila tradicionalna evropska literarna veda? V čem se razlikuje literatura, ki temelji na zapisanem tekstu, in književnost, ki se prenaša ustno? Kakšna je njuna ontološka in hermenevtična narava? Preučevanje teh vprašanj na žalost presega obseg te razprave.

106 Schmitz, Modern Literary Theory, 82.
} 
tekst? Ali intertekstualnost tragedije neupravičeno predpostavlja, da je primarni sprejemnik tragedijo razumel kot literarno delo? Menim, da ja. Prvotni kontekst in upoštevanje horizonta pričakovanja primarnih sprejemnikov namreč nasprotujeta prepričanju, da je tragedija Orest literarno delo v sodobnem pomenu besede. In s tem seveda nasprotujeta tezi o intertekstualni naravi te Evripidove tragedije.

\section{d) Sklepne besede: intertekstualnost, da in ne}

Kaj lahko torej na koncu rečemo o intertekstualnosti Evripidove tragedije Orest? Fowler v svojem spisu o intertekstualnosti nekaj prostora nameni tudi razmisleku o intertekstualnosti s stališča teorije bralčevega odziva, ki sem se je v svoji kritiki vloge intertekstualnosti v Orestu posluževal tudi sam. Tako se opre na post-strukturalistično razumevanje literarnega dela in trdi, da je slednje sestavljeno »iz neskončne verige intertekstualnih navezav, ${ }^{107}$ tako da je vsaka točka, na kateri se ustavimo, povsem naključna «. ${ }^{108}$ Vsaka interpretacija besedila, ki je po svoji naravi pomensko neskončno odprta, je torej povsem odvisna od same recepcije, tako da je vedno zgolj bralec tisti, ki ustvarja pomen literarnega dela. ${ }^{109}$ Prav v tem pogledu bi lahko bilo tudi intertekstualno razumevanje Evripidove tragedije Orest povsem legitimno. Če torej do tragedije pristopamo s horizontom sodobnega bralca, ki tragedijo bere najprej in predvsem kot literarno delo, je teza o intertekstualnosti Oresta sprejemljiva.

V nasprotju s Fowlerjem pa Mastronarde trdi, da vsi momenti različnih recepcij ne morejo biti enakovredni, sploh ne s stališča klasične filologije. Po njegovem mnenju je prav širši kontekst tragedije bistven za njeno razumevanje $^{110}$. In vendar! Četudi je razumevanje Oresta kot intertekstualnega dela sprejemljiva interpretacijska tehnika, pa se ne morem strinjati z zaključki $\mathrm{F}$. Zeitlin. Njene ugotovitve o izčrpanju tragedije kot forme, o prehodu iz mita $\mathrm{v}$ literaturo ter o avtorefleksivnem umetniškem delu so pretirane, saj se osredotočajo predvsem na samo naravo tragiškega dela. Ker so ta vprašanja predvsem domena literarne ontologije in hermenevtike (ne pa gole interpretacije), bi raziskava morala upoštevati tudi primarni kulturni in zgodovinski kontekst tragedije: torej njen ritualni in performativni kontekst, naravo tragiškega jezika, vlogo ustne tradicije in podobno. Tako lahko zaključimo, da je interteks-

107 To je pravzaprav pozicija poststrukturalizma in dekonstrukcije.

108 Fowler, »On the Shoulders«, 13.

109 Vendar pa je Fowlerjeva pozicija specifična: sam namreč ne ugovarja interpretaciji Shakespeara, ki bi iskala intertekstualne povezave z deli T.S. Eliota, čeprav je slednji živel kar nekaj stoletji po velikem angleškem pesniku (Fowler, »On the Shoulders«, 15). Še več, zagovarja celo, da je celotno razumevanje klasičnih literarnih del povsem odvisno od kasnejšega izročila in da so "vse naše konstrukcije antike odvisne od modernih zgodb « (Fowler, "On the Shoulders", 14). Čeprav je morda ta teza precej provokativna, težko trdimo, da je povsem zgrešena. Za delno potrditev ali vsaj podrobnejši razmislek o tej tezi, glej na primer delo Jeana Sezneca La survivance des dieux antiques.

110 Mastronarde, The Art of Euripides, 47. 
tualna interpretacija Oresta sicer legitimna interpretacijska metoda, a je sklep o njeni intertekstualni in strukturalistični naravi s stališča njenega konteksta pretiran. Vsaj po svoji ontološki in hermenevtični funkciji Evripidov Orest ni in ne more biti intertekstualna tragedija. ${ }^{111}$

\section{BIBLIOGRAFIJA}

\section{Viri prevodov}

Ajshil. Oresteja. Prev. M. Maričič. Ljubljana: Modrijan, 2008.

Evripid. Medeja, Ifigenija pri Tavrijcih. Prev. M. Marinčič. Ljubljana: Mladinska knjiga, 2000.

Homer. Odiseja. Prev. K. Gantar. Ljubljana: DZS, 1982.

\section{Druga literatura}

Allen, Graham. Intertextuality. London: Routledge, 2000.

Baraz, Yelena in van der Berg, Cristopher S. "Intertextuality. Introduction«. AJPh 134 (2013): 1-8.

Barthes, Roland. »Smrt avtorja.« V: Sodobna Literarna Teorija. 19-23. Ljubljana: Krtina, 1995.

Bonnefoy, Yves. »Odmakniti pogled od knjige«. Nova Revija 26 (2007): 342-52.

Bratož, Rajko. Grška zgodovina. Ljubljana: Zveza zgodovinskih društev Slovenije, 2003.

Burgess, Jonathan. "Neoanalysis, Orality, and Intertextuality: An Examination of Homeric Motif Transference«. Oral Tradition 21 (2006). 148-89.

Cancik, Hubert, Schneider, Helmuth, Landfester, Manfred, Salazar, Christine F., Gentry, August, Francis G., in Pauly, F. Brill's New Pauly. Leiden: Brill, 2007.

Chong-Gossard, J. H. Kim On. Gender and communication in Euripides' plays between song and silence. Leiden: Brill. 2008.

Crouter, Richard. Friedrich Schleiermacher: Between Enlightenment and Romanticism. Cambridge, UK: Cambridge University Press, 2005.

Culler, Jonathan D. Structuralist Poetics: Structuralism, Linguistics and the Study of Literature. London: Routledge. 2008.

Easterling Patricia, E. »Tragedy and Ritual. Cry 'Woe, Woe', but May the Good Prevail!«. Métis 3 (1988): 87-109.

Euripides, Peck, John, and Nisetich Frank J. Orestes. New York: Oxford University Press, 1995.

Fowler, Don P. »On the Shoulders of Giants: Intertextuality and Classical Studies.« $M D$ 39 (1997). 13-34.

Frank, Manfred. »Besedilo in njegov slog: Schleiermacherjeva teorija jezika.« Nova Revija 304/306 (2007). 208-24.

. »Kaj je literarno besedilo in kaj pomeni njegovo razumevanje?« Nova Revija 304/306 (2007). 225-76.

111 Najlepše se zahvaljujem dr. Branetu Senegačniku za vso pomoč in podporo pri nastanku tega besedila. 
Freeman, Kenneth J. Schools of Hellas. New York: Teachers College Press, 1969.

Genette, Gérard. Palimpsests: literature in the second degree. Lincoln: University of Nebraska Press. 1997.

Harris, Jonathan. Art History: the Key Concepts. London: Routledge. 2006.

Heidegger, Martin. »Izvir umetniškega dela.« V: Izbrane razprave. Ljubljana: Cankarjeva založba, 1967.

Heidegger, Martin. Na Poti Do Govorice. Ljubljana: Slovenska matica, 1995.

Heidegger, Martin. Razjasnjenja ob Hölderlinovem pesništvu. Ljubljana: Nova revija, 2001.

Hinds, Stephen. Allusion and Intertext. Cambridge: Cambridge University Press, 1998.

Juvan, Marko. Intertekstualnost. Ljubljana: DZS, 2000.

Klein, Michael Leslie. Intertextuality in Western Art Music. Bloomington, Indiana: Indiana University Press. 2005.

Koron, Alenka. Sodobne teorije pripovedi. Ljubljana: Založba ZRC, 2014.

Kristeva, Julia. »Bakhtine. Le mot, le dialogue et le roman.« Critique 239 (1967): 438-65.

- Desire in language: a semiotic approach to literature and art. New York: Columbia University Press. 1980.

- La révolution du langage poétique. Paris: Éditions du Seuil, 1974.

Marinčič, Marko. Grška književnost arhaične dobe: zgodovinski, problemski in bibliografski uvod. Ljubljana: Filozofska fakulteta Univerze v Ljubljani, 2004.

Martin, Elaine. »Intertextuality: An introduction. "The Comparatist 35 (2011): 148-51.

Mastronarde, Donald J. The Art of Euripides: Dramatic Technique and Social Context. Cambridge: Cambridge University Press, 2010.

McAfee, Noëlle. Julia Kristeva. New York: Routledge. 2004.

Murray, Gilbert. Euripide: Fabulae: 3. Oxonii. Clarendoniano, 1913. Weed, N. The Orestes of Euripides. Cambridge: University Press, 1895.

Nicholson, Nigel. »Cultural Studies, Oral Tradition, and the Promise of Intertextuality«. AJPh 134 (2013): 9-21.

Orr, Mary. Intertextuality: Debates and Contexts. Cambridge, UK: Polity, 2003.

Pomeroy, Sarah B. A Brief History of Ancient Greece: Politics, Society, and Culture. New York: Oxford University Press, 2004. . Ancient Greece: A Political, Social, and Cultural History. New York,

Porter, John R. Studies in Euripides' Orestes. Leiden: E.J. Brill, 1994.

Riffaterre, Michael. Semiotics of poetry. Bloomington: Indiana University Press. 1978.

Saussure, Ferdinand de. Predavanja iz splošnega jezikoslovja. Prev. Boštjan Turk. Ljubljana: Studia Humanitatis. 1997.

Schmitz, Thomas A. Modern Literary Theory and Ancient Texts: an Introduction. Malden, Mass: Blackwell, 2007.

Scodel, Ruth. An Introduction to Greek Tragedy. Cambridge in New York: Cambridge University Press, 2010.

Segal, Charles. »Song, Ritual, and Commemoration in Early Greek Poetry and Tragedy.» Oral Tradition 4 (1989). 330-59.

Senegačnik, Branko. »Klasična atiška tragedija.» V: Ajshil: Pribežnice. Celje: Celjska Mohorjeva družba, 2008.

Seznec, Jean. La Survivance Des Dieux Antiques: Essai Sur Le Rôle De La Tradition Mythologique Dans L'humanisme Et Dans L'art De La Renaissance. London: Warburg Institute, 1940.

Snoj, Vid. »O Literaturi Drugače.» Primerjalna književnost (2010): 181-97. 
Sourvinou-Inwood, Christiane. Tragedy and Athenian Religion. Lanham, Md: Lexington Books, 2003.

Starobinski, Jean. Les mots sous le mots: les anagrammes de Ferdinand de Saussure. Paris: Gallimard. 2009.

Torrance, Isabelle. Metapoetry in Euripides. Oxford: Oxford University Press, 2013. Vernant, Jean-Pierre. Začetki grške misli. Ljubljana: Državna založba Slovenije, 1986.

Virk, Tomo. Moderne metode literarne vede in njihove filozofsko teoretske osnove. Ljubljana: Filozofska fakulteta, 2003.

—. Primerjalna književnost na prelomu tisočletja. Ljubljana: Založba ZRC, ZRC SAZU. 2007.

Vološinov, V. N. Marxism and the Philosophy of Language. Cambridge, Mass: Harvard University Press. 2000.

West, M. L. »The Early Chronology of Attic Tragedy«. CQ 39 (1989): 251- 254.

Whitmarsh, Tim. Ancient Greek Literature. Cambridge, UK: Polity Press, 2004.

Worton, Michael in Judith Still. Intertextuality: Theories and practices. Manchester: Manchester University Press. 1990.

Wright, Matthew E. "Enter a Phrygian (Euripides Orestes 1369).« GRBS 48 (2008): 5-13.

- Euripides: Orestes. London: Duckworth, 2008.

Zabel, Blaž. »Roland Barthes in urbanizem.«Praznine 6 (2014): 57-59.

Zeitlin, Froma. "The Closet of Masks: Role-Playing and Myth-making in the Orestes of Euripides.« V: Euripides, ur. Judith Mossman, 309-337. Oxford: Oxford University Press, 2003.

\section{INTERTEXTUALITY IN ANCIENT GREEK TRAGEDY: THE CASE OF EURIPIDEAN ORESTES}

\section{Summary}

The paper discusses the role of intertextuality in the tragedy Orestes written by Euripides. In the first part of the paper, I provide an overview of theories about intertextuality, especially those from the domain of structuralism. First, I present Saussure's linguistic theory and continue with discussing intertextual theories by Mikhail Bakhtin, Julia Kristeva, Roland Barthes, Michael Riffaterre, and Gérard Genette. Moreover, the implications for literary ontology and interpretation are discussed and it is argued that structuralists perceive literature as an autonomous, self-sufficient and non-referential system of literary works. In the second part of the paper, the theoretical implications of intertextuality for classical philology are discussed and a quick overview of its reception is presented. Furthermore, a literature review of intertextuality in Orestes is provided and particular examples of intertextual references to Oresteia, Medea, Iphigenia in Tauris, and Odyssey are discussed. Froma Zeitlin argues in her paper The Closet of Masks: Role-Playing and Myth-making in the Orestes of Euripides that Orestes is autonomous, literary and self-reflective work of art, a text in the system of literature, that it is no longer a tragedy, since 
the genre has exhausted itself and moved from mythic fact to fiction are all linked to the structuralist conception of literature and intertextuality. These conclusions are thoroughly analysed in the paper. In the concluding part of the paper I present three possible objections to Zeitlin's argument. In my argumentation I follow Mastronarde's reception-theory position. In this regard I take into account the original context of reception and the horizons of expectations of primary recipients. In the first objection I thus discuss the broader cultural context of the tragedy, its relation to the ritual and its consequences for the interpretation of Orestes. Second, I consider the nature of language in tragedy and in Orestes, confronting structuralist and Manfred Frank's theory of language. Third, I examine the relation between the Greek tragedy, the oral tradition and the role of intertextuality in both. As I demonstrate, all three objections support the conclusion that Orestes is not an intertextual work, at least if the original cultural context and horizons of expectations of primary recipients are considered. 